\title{
PHARMACOLOGICAL STUDIES ON PLANTS BELONGING TO THE FAMILY LEGUMINOSAE
}

\author{
AARUSHI KUMAR ${ }^{1}$, F. R. JOBI XAVIER ${ }^{2}$ \\ Department of Life Sciences, Christ (Deemed To Be University), Hosur Road, Bengaluru-29, Karnataka India \\ Email: aarushi.kumar@science.christuniversity.in
}

Received: 22 Jan 2020, Revised and Accepted: 23 Mar 2020

\section{ABSTRACT}

Objective: The study is an attempt to quantitatively measure the presence of Anti-Parkinsons drug Levodopa in members of the family Leguminosae.

Methods: Reverse phase HPLC, Phytochemical analysis carried out using Bioinformatic tools (ChemMine and Cytoscape). The dried seed samples of Mucuna pruriens (Linn.), Cassia fistula (Linn.), Lathyrus odoratus (Linn.), Glycine max (L. Merr.), and Mimosa pudica (L) were selected for the study of Levodopa, and compared with-Tecoma stans from the family Bignoniaceae., and antimicrobial activity was conducted on selected bacteria.

Results: Mucuna pruriens showed the presence of Levodopa in quantifiable higher quantity i.e., $705.5985 \mu \mathrm{g} / 20 \mathrm{ml}$, whereas other plant samples contained very less quantity. The antimicrobial activity of the selected plants on E. coli and Bacillus showed positive results.

Conclusion: The study proves the presence of Anti-Parkinsons drug Levodopa in Mucuna pruriens, whereas absent in the other plants. The selected plants prove the anti-bacterial activity on the selected bacteria.

Keywords: Levodopa; HPLC, Mucuna pruriens, Anti-microbial activity, Cheminformatics

(C) 2020 The Authors. Published by Innovare Academic Sciences Pvt Ltd. This is an open access article under the CC BY license (http://creativecommons.org/licenses/by/4.0/) DOI: http://dx.doi.org/10.22159/ijcpr.2020v12i3.38330. Journal homepage: https://innovareacademics.in/journals/index.php/ijcpr

\section{INTRODUCTION}

Dr. James Parkinson first described Parkinson's disease (PD) also known as the "Shaking palsy", It can be described as the chronic, progressive neurodegenerative disease which is characterized by the motor and nonmotor features. The shaking palsy is also known as the Paralysis Agitans [1]. The term parkinsonism is basically used to define the complex symptoms of the disease [2].

PD is among the most common disease of neurodegenerative disorders. Parkinson's disease foundation reports that almost 1 million people are affected with the disease currently $[3,4]$.

From the clinical point of view, the symptoms of PD are: bradykinesia, rigidity, resting tremor and postural instability. Levodopa is a neutral, large amino acid which is synthesized from Lthyroxine through hydroxylation, followed by decarboxylation to form the end product as the dopamine, which is a neurotransmitter that lacks the ability to pass the blood-brain barrier [5]. Thus, the levodopa is used as a drug which has the ability to pass the bloodbrain barrier.

Levodopa is the precursor of dopamine. When levodopa or L-dopa is converted to dopamine and crosses the blood-brain barrier and helps in the proper functioning of the central nervous system via the synapsis. Levodopa converts to dopamine and crosses the bloodbrain barrier and prevents the Parkinson's disease [6].

Levodopa is the symptomatic treatment of Parkinson's disease. It is considered as the most effective drug for the same and provides better symptomatic control, it is one of the potent drugs for the curing of the disease. This aromatic amino acid, 1-3,4-dihydroxy phenylalanine has always been the most important drug from past half century. This Ldopa passes the blood-brain barrier and thereby increases the amount of dopamine near the brain cells, whereas the dopamine itself cannot do that and thus leads to the incurable disease. This dopamine and its precursor play an important role both in Parkinson's disease as well as the dopamine responsive dystonia [7].

Parkinson's disease is a neurological disease related to the central nervous system wherein the movement of the body is affected, which is sometimes accompanied by tremors. This disease is more common in the people belonging to the age group of 45-60 and above. This disease is not curable but the condition can only be improved by the proper medication. Parkinson's disease is a neurological disease related to the central nervous system wherein the movement of the body is affected, which is sometimes accompanied by tremors. This disease is more common in the people belonging to the age group of 45-60 and above. This disease is not curable, but the condition can only be improved by the proper medication [8].

PubChem being the online database for the chemical structures, the phytochemicals which were downloaded using IMPPAT, the phytochemical structure and canonical smiles were downloaded as PubChem gives proper data for each input these ids and smiles were then again verified using Classyfire which is a database, which basically aims at classifying the compound's family and subgroups. This classification helps in understanding the classification of each phytochemical and its similarities with other phytochemicals of other plants. Whereas the PubChem is an online database which is designated to solely give information related to the chemical information, having its resource at the U. S. National Centre for Biotechnology Information (NCBI). This was launched in the year 2004. PubChem organizes the data into three inter-linked databases, which includes Substance, Compound and Bioassay [9]. PubChem is the public repository for information on chemicals [10]. The desire to classify almost all the chemical compounds up to the subfamily and subclass was made possible through a comprehensive, flexible and completely computable as well as purely structure-based chemical taxonomy along with a computer program was made into existence, Classy Fire having data for almost $>4800$ different categories of chemical compounds, and up to 11 different levels of categories of classification whereas each category is defined as per the nomenclature and in English. The database is freely accessible [11].

\section{Mucuna pruriens (Linn.)}

L-dopa is naturally present in the Mucuna pruriens (Linn.) this is commonly known as The Magic Velvet Beans or Kauchbeej in Hindi. The plant belongs to the Leguminosae family; subfamily Papilionacae plant plays a major role in the treatment of Parkinsonism [12]. 
The amount of levodopa present in the seeds are quantified using HPLC densitometry and the concentration ranges from $0.58-6.42(\%$, dr. wt.) $[13,14]$.

\section{Cassia fistula (Linn.)}

The tree is commonly known as the golden shower tree, and is usually known for its medicinal purposes, also showing the mild laxative property which was found effective in children and pregnant ladies. In the traditional medicines this plant is known in Ayurveda to Unani and is used as infusion, decoction or powder [15]. The seeds of cassia fistula contain nearly about $24 \%$ of protein which is higher than most of the plants having protein and is also considered as the important source of lectins [16]. According to the Pharmacological studies, the plant is used for Central Nervous System Activities apart from other medicinal uses [17].

\section{Lathyrus odoratus (Linn.)}

The plant is represented by more than 200 species worldwide, which includes 75 taxa, of which 18 species are endemic. The plant shows various therapeutic properties due to its pharmacological activities like anti-oxidant, anti-cancer, anti-inflammatory etc. The plant also has nutraceutical properties as well [18].

\section{Glycine max (L. Merr.)}

Soybean or (Glycine max L. Merr.) is considered as the fourth most important crop in the world when it comes to harvesting and production. It is also considered as one of the cheapest sources of oil as well as the protein source [19]. The plants show various therapeutic properties due to its pharmacological activities like antioxidant, anti-cancer, anti-inflammatory etc. The plant also has nutraceutical properties as well [20,21].

\section{Mimosa pudica (L)}

Mimosa belonging to the family Mimosae, commonly known as the Lajvanti or chuimui in local Hindi language and touch me not plant in English [22]. The plant is identified to have antiasthmatic, aphrodisiac, analgesic, and anti-depressant properties. The phytochemical studies reveal the presence of alkaloids and flavonoids, including some nonprotein amino acids like Mimosine. The plant shows the active presence of terpenoids, flavonoids, Glycosides, alkaloids etc. [23].

\section{Tecoma stans (L) Juss Ex. Kunth}

Tecoma belonging to the family Bignoniaceae is also commonly known as the yellow elder tree, which exactly comes under erect shrub or a small tree [24].

The plant has numerous monoterpenic alkaloids, triterpenoids and phenolics, like chlorogenic, caffeic, vanillicetc. The bioactive compounds that are present are exhibiting various pharmacological activities for e. $g$. Antioxidant, antimicrobial and antifungal activities [25].

\section{MATERIALS AND METHODS}

\section{Collection of plants}

The selected plant seeds were purchased online through Amazon. com. Inc. (https://www.amazon.in/) [26], through a verified seller of horticulture grade.

\section{Sample preparation}

\section{Antibacterial activity}

The plant seeds were made into fine powder using the home grinder. The fine powder obtained was stored in the airtight containers. This powder was used for testing the antibacterial activity.

\section{Estimation of Levodopa}

The seed powder was used for the estimation of the compound. The mobile solvent was prepared with acetonitrile: water in the ratio 50 : 50 , the extraction solvent was also kept the same.

\section{Phytochemical profiling}

The phytochemicals for all the selected plants were downloaded using the IMPAAT database. A datasheet was prepared using Microsoft Excel@ 2019, where the IUPAC name, as well as the
Canonical SMILES, were noted down, along with the PubChem ID and Inchl Key, the data was then analyzed using the ChemMine and Cytoscape. The phytochemical classes were also noted down using ClassyFire.

\section{Estimation of levodopa}

The standard was first prepared using the pure L-dopa HPLC grade which was brought online from SLS Chemicals Chennai; the standard was prepared in the same solvent extraction system, which was used for the extraction of L-dopa. The solvent system which was used for the seeds of the above plant samples. $1 \mathrm{~g}$ of this seed sample was taken and was mixed with $5 \mathrm{ml}$ of acetonitrile: water and was sonicated for 5 min followed by the addition of $5 \mathrm{ml}$ of the solvent and instead of centrifugation at $10,000 \mathrm{rpm}$ for $5 \mathrm{~min}$, the protocol was modified to $10,000 \mathrm{rpm}$ for $15 \mathrm{~min}$. after which this supernatant was assessed in HPLC by using the mobile phase that is acetonitrile: water: formic acid in the ratio 50:50:1 but was further changed to acetonitrile: water in the ratio $1: 1$, the results were analyzed $[27,28]$.

\section{Phytochemical profiling}

Literature [29], along with some public data banks were extensively searched for the phytochemicals present in all the selected plants and a dataset was generated where the structure of these phytochemicals was downloaded from PubChem and the chemical properties were studied from the data available on ClassyFire, using cytoscape a graph was made to understand the phytochemicals better $[11,30]$.

\section{Antibacterial activity}

The seed of all the selected plants i.e. Mucuna pruriens, Mimosa pudica, Cassia fistula, Lathyrus odoratus, Glycine max and Tecoma stans were brought online through Amazon India. The seeds were sun dried followed by the oven drying at $60^{\circ} \mathrm{C}$ until the seeds were dried enough to grind. The seeds were then made to fine powder and this powder was stored in air-tight bottles. $0.1 \mathrm{~g}, 0.5 \mathrm{~g}$ and $1.0 \mathrm{~g}$ of the seeds were weighed and was added to the $500 \mathrm{ml}$ autoclaved water to prevent any contamination. To this water already subcultured loop of $E$. coli and Bacillus were added and the water was allowed to incubate for $3 \mathrm{~h}$. After which the protocol was slightly modified and further the water was incubated for $30 \mathrm{~min}, 60 \mathrm{~min}$ and 120 min and before plating the contaminated water was diluted in the ratio 1:5 and was plated on the agar medium using simple spread plate method and was incubated overnight in the incubator at $35{ }^{\circ} \mathrm{C}$. The colonies were counted the next day [31].

\section{RESULTS}

\section{Estimation of levodopa in plant samples}

The retention time for M. pruriens was noted down to be 6.132 with a tail factor of 1.82 whereas the concentration was observed in mAU of 22366.000; therefore the amount of levodopa was quantified from the fig. 1 as well as from fig. 7 and was found out to be $705.5985 \mu \mathrm{g} / 20 \mu \mathrm{l}$.

The retention time $C$. fistula was noted down to be 6.682 with a tail factor of 1.59, whereas the concentration was observed in $\mathrm{mAU}$ of 5695.000 , therefore the amount of levodopa quantified from the fig. 2 as well as from fig. 7 and was found out to be $257.8075 \mu \mathrm{g} / 20 \mu \mathrm{l}$.

The retention time L. odoratus was noted down to be 6.832 with a tail factor of 1.56, whereas the concentration was observed in $\mathrm{mAU}$ of 100.000 , therefore the amount of levodopa was quantified from the fig. 3 as well as from fig. 7 and was found out to be $100.000 \mu \mathrm{g} / 20 \mu \mathrm{l}$.

The retention time G. max was noted down to be 6.948 with a tail factor of 1.46, whereas the concentration was observed in mAU of 100.000; therefore the amount of levodopa was quantified from the fig. 4 as well as from fig. 7 and was found out to be $100.000 \mu \mathrm{g} / 20 \mu \mathrm{l}$.

The retention time M. pudica was noted down to be 6.422 with a tail factor of 1.32, whereas the concentration was observed in $\mathrm{mAU}$ of 5062.000 , therefore the amount of levodopa was quantified from the fig. 5 as well as from fig. 7 and was found out to be $192.0065 \mu \mathrm{g} / 20$ $\mu \mathrm{l}$. 


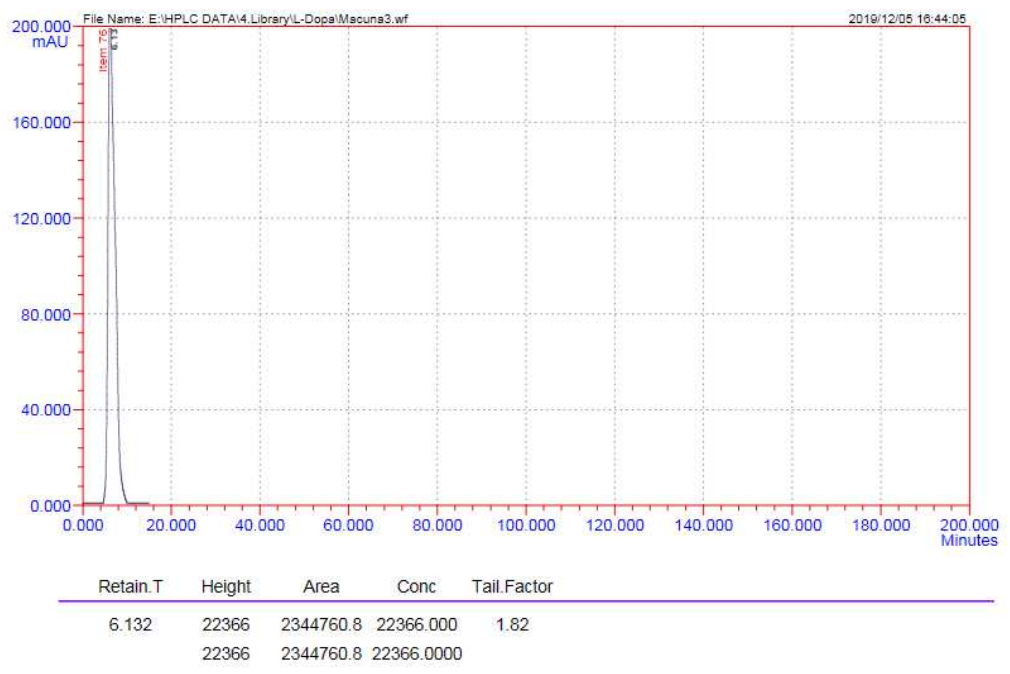

Fig. 1: Quantification of L-dopa present in the seeds of M. pruriens

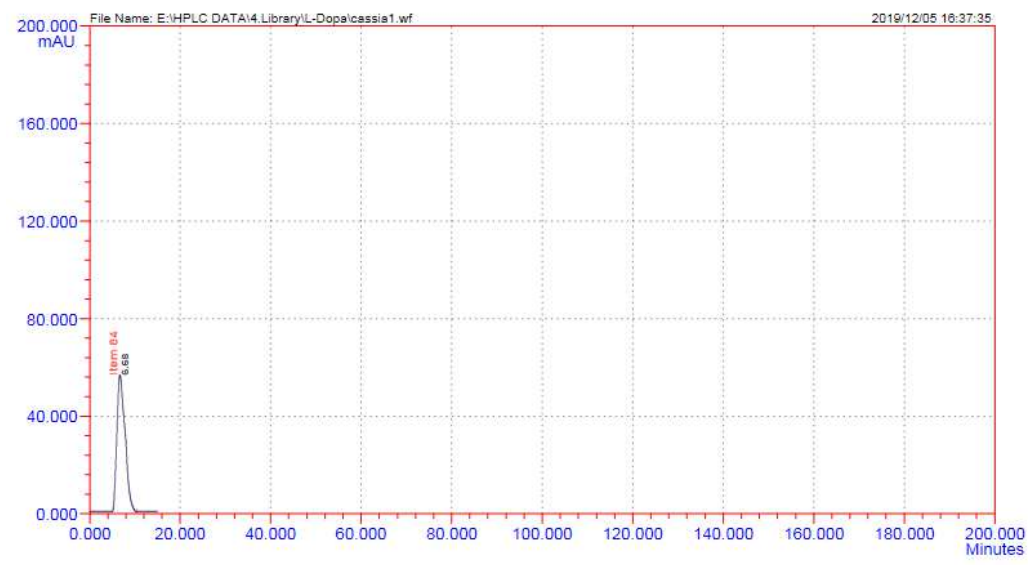

\begin{tabular}{ccccc} 
Retain.T & Height & Area & Conc & Tail.Factor \\
\hline \multirow{2}{*}{6.682} & 5695 & 736851.6 & 5695.000 & 1.59 \\
& 5695 & 736851.6 & 5695.0000 &
\end{tabular}

Fig. 2: Quantification of L-dopa present in the seeds of C. fistula

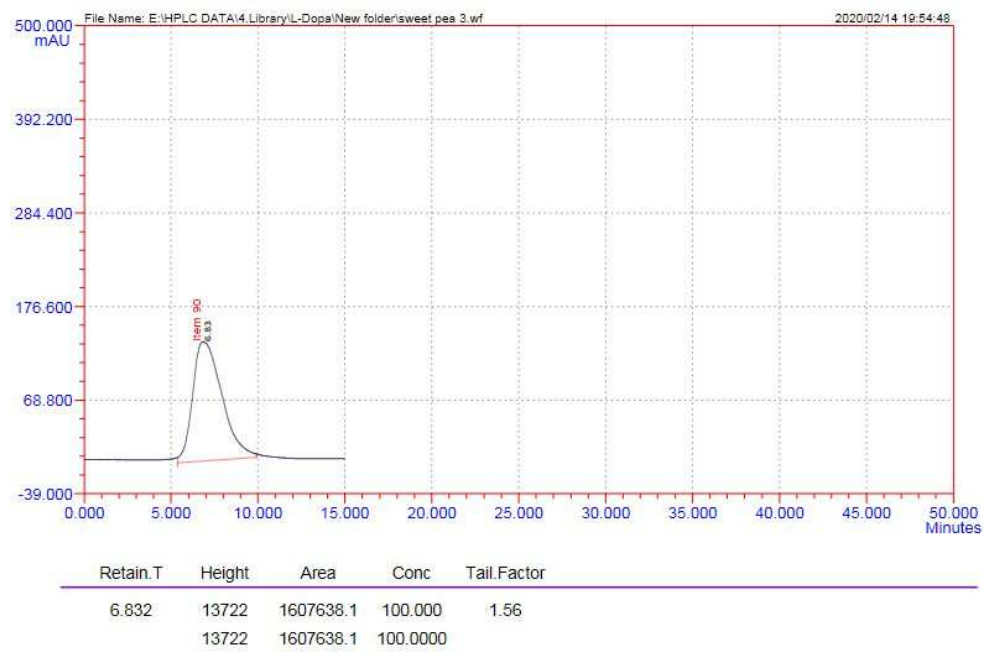

Fig. 3: Quantification of L-dopa present in the seeds L. odoratus 


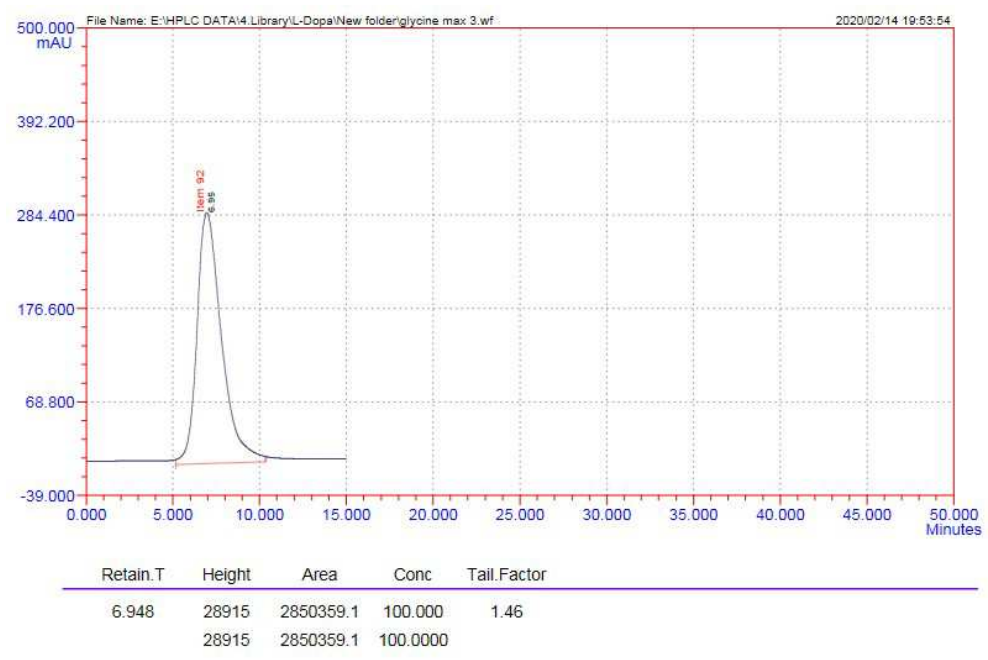

Fig. 4: Quantification of L-dopa present in the seeds of G. max

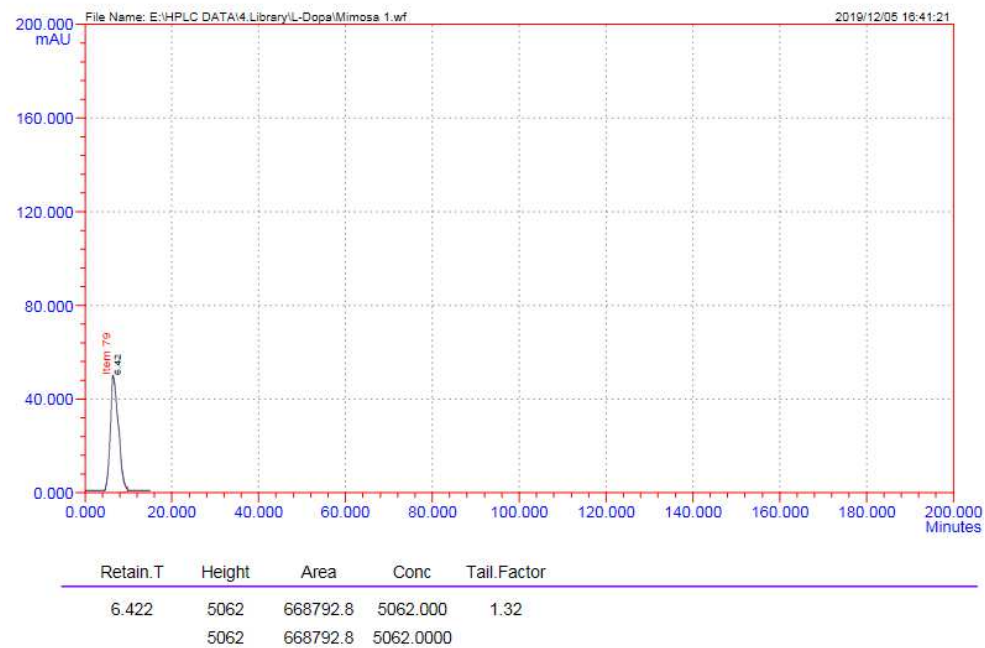

Fig. 5: Quantification of L-dopapresent in the seeds of M. pudica

The retention time T. stans was noted down to be 6.788 with a tail factor of 1.55 whereas the concentration was observed in $\mathrm{mAU}$ of
100.000 , therefore the amount of levodopa was quantified from the fig. 6 as well as from fig. 7 and was found out to be $100 \mu \mathrm{g} / 20 \mu \mathrm{l}$.

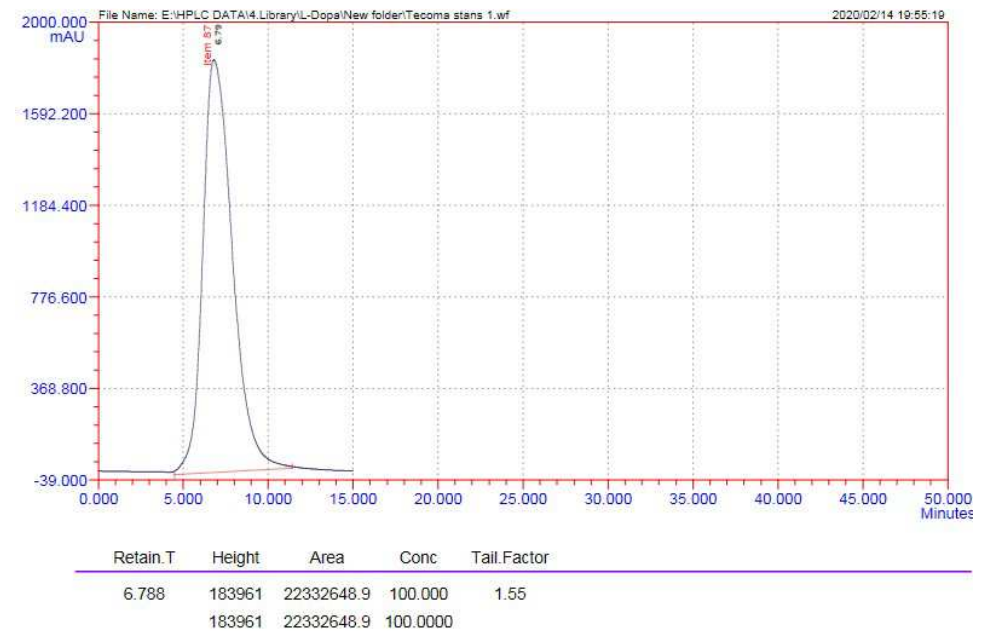

Fig. 6: Quantification of L-dopa present in the seeds of T. stans 


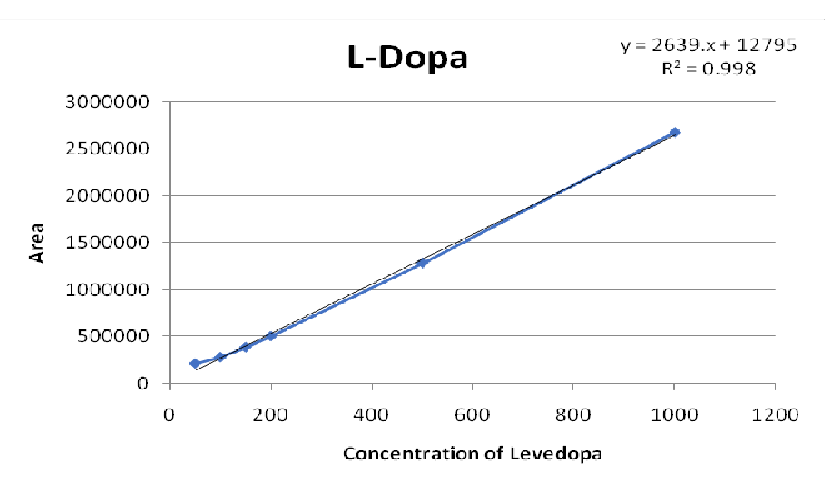

Fig. 7: The standard graph of L-dopa

Table 1: Concentration of L-dopa in plant samples

\begin{tabular}{ll}
\hline Plant sample & Amount of L-dopa (in $\boldsymbol{\mu g} / \mathbf{2 0} \boldsymbol{\mu l})$ \\
\hline Mucuna pruriens & 705.5985 \\
Cassia fistula & 257.8075 \\
Lathyrus odoratus & 100.0000 \\
Glycine max & 100.0000 \\
Mimosa pudica & 192.0065 \\
Tecoma stans & 100.0000 \\
\hline
\end{tabular}

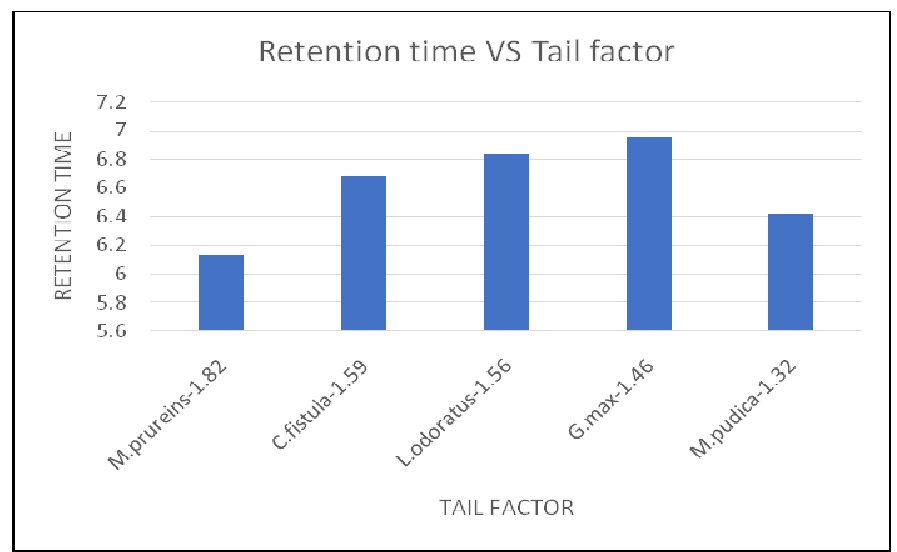

Fig. 7: The graph representing the relation between the retention time and the tail factor while $M$. pruriens is equivalent with the standard graph

The concentration of the compound was calculated using the standard graph of L-dopa, which was prepared using the pure Ldopa of HPLC grade.

The quantification of levodopa was done through reverse phase HPLC, using Acetonitrile: water in the ratio 50:50 as the mobile phase. After the run time of $15 \mathrm{~min}$ and temperature set to $35^{\circ} \mathrm{C}$, the tail factor as well as the retention time of the compounds were analyzed with the standard graph of Levodopa. A graph was also plotted for retention time vs tail factor to understand the difference between the plant species in this perspective.

HPLC was conducted on all the six plants, whereas T. stans belonging to entirely different family and sub-class i.e. Bignoniaceae and gamopetalae whereas rest of the five plants belongs to the family of Leguminosae and sub-class polypetalae.

The concentration of the compound was calculated with the standard, where Mucuna pruriens showed the presence of the compound in the quantifiable quantity, whereas the other plant samples neither matched the retention time as well as the tail factor with the standard as well as the Mucuna pruriens, The concentration of the compound was also not in the quantifiable quantity.

The concentration in M. prureins was found to be $705.5985 \mu \mathrm{g} / 20 \mu \mathrm{l}$ [table 1]

For the further understanding of the absence of levodopa in other plant samples, in silico methods were adopted for better understanding. The result showed no presence of similarity in the phytochemicals present in them. Showing no similarity even among the plant samples belonging to the family Leguminosae.

Drug family was identified using Classyfire to verify with ChemMine and Cytoscape.

\section{Statistical analysis of the data}

For further analysis statistical analysis was conducted on the data [table 2], the main aim to do the analysis was to understand the significance of plants in relation to the compound obtained.

\section{Anti-microbial activity towards selected bacteria}

Following colonies were seen [table 3] for E. coli and Bacillus, for the following concentration of the seed powder of M. pruriens 


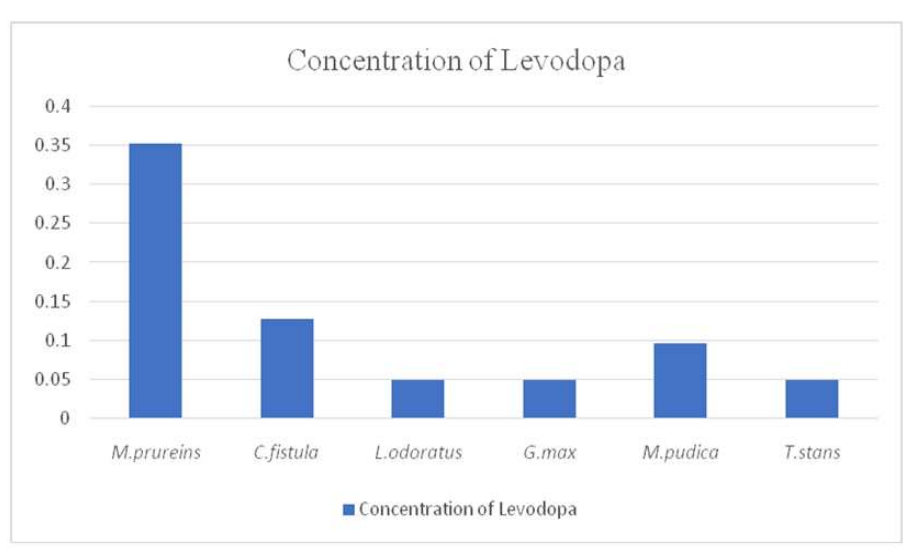

Fig. 9: Graphical representation of concentration of Levodopa

Table 2: Tests of between-subjects effects ANOVA-one way dependent variable: plant species

\begin{tabular}{|c|c|c|c|c|c|}
\hline Source & Type III sum of squares & df & Mean square & $\mathbf{F}$ & Sig. \\
\hline Corrected Model & $12.833^{\mathrm{a}}$ & 3 & 4.278 & 1.833 & .372 \\
\hline Intercept & 45.633 & 1 & 45.633 & 19.557 & .048 \\
\hline L-Dopa Conc. & 12.833 & 3 & 4.278 & 1.833 & .372 \\
\hline Error & 4.667 & 2 & 2.333 & & \\
\hline Total & 91.000 & 6 & & & \\
\hline Corrected Total & 17.500 & 5 & & & \\
\hline
\end{tabular}

$\mathrm{a}=$ Corrected model with the significance value of 0.372 which is greater than 0.05 thus the, $\mathrm{P}>0.05$ i.e. there is no significance, $\mathrm{b}=$ Intercept with the significance value of 0.048 which is lesser than 0.05 thus $\mathrm{P}<0.05$ i.e. there is significance.

Table 3 Colonies for M. pruriens

\begin{tabular}{lllllll}
\hline E. coli & & & & Bacillus & \\
\hline Time in & $\mathbf{0 . 1 g}$ & $\mathbf{0 . 5 g}$ & $\mathbf{1 . 0 g}$ & $\mathbf{0 . 1 g}$ & $\mathbf{0 . 5 g}$ & 1.0g \\
min & Plant sample & Plant sample & Plant sample & Plant sample & Plant sample & Plant sample \\
\hline 30 & 73 & 0.0 & 0.0 & 133.0 & 2.0 & 133.0 \\
60 & 80 & 0.0 & 0.0 & 84.0 & 5.0 & 247.0 \\
120 & 119 & 0.0 & 0.0 & 129.0 & 9.0 & $>500$ \\
\hline
\end{tabular}

Following colonies were seen [table 4] for E. coli and Bacillus, for the following concentration of the seed powder of C. fistula

Table 4: Colonies of C. fistula

\begin{tabular}{|c|c|c|c|c|c|c|c|}
\hline E. coli & & & & Bacillus & & & \\
\hline Time in min & $\begin{array}{l}0.1 \mathrm{~g} \\
\text { Plant sample }\end{array}$ & $\begin{array}{l}0.5 \mathrm{~g} \\
\text { Plant sample }\end{array}$ & $\begin{array}{l}1.0 \mathrm{~g} \\
\text { Plant sample }\end{array}$ & $\begin{array}{l}\text { 0.1g } \\
\text { Plant sample }\end{array}$ & $\begin{array}{l}0.5 \mathrm{~g} \\
\text { Plant sample }\end{array}$ & $\begin{array}{l}1.0 \mathrm{~g} \\
\text { Plant sample }\end{array}$ & Control \\
\hline 30 & 584.0 & $>500$ & 4.0 & $>500$ & $>500$ & $>500$ & 4.0 \\
\hline 60 & $>500$ & $>500$ & 32.0 & $>500$ & $>500$ & $>500$ & - \\
\hline 120 & $>500$ & $>500$ & 138.0 & $>500$ & $>500$ & $>500$ & 1459 \\
\hline
\end{tabular}

Following colonies were seen [table 5] for E. coli and Bacillus, for the following concentration of the seed powder of L. odoratus.

Table 5: Colonies of L. odoratus

\begin{tabular}{|c|c|c|c|c|c|c|c|}
\hline E. coli & & & & Bacillus & & & \\
\hline Time in minutes & $\begin{array}{l}\text { 0.1g } \\
\text { Plant sample }\end{array}$ & $\begin{array}{l}0.5 g \\
\text { Plant sample }\end{array}$ & $\begin{array}{l}1.0 \mathrm{~g} \\
\text { Plant sample }\end{array}$ & $\begin{array}{l}\text { 0.1g } \\
\text { Plant sample }\end{array}$ & $\begin{array}{l}0.5 g \\
\text { Plant sample }\end{array}$ & $\begin{array}{l}1.0 \mathrm{~g} \\
\text { Plant sample }\end{array}$ & Control \\
\hline 30 & 584.0 & $>500$ & 32 & $>500$ & $>500$ & $>500$ & 4.0 \\
\hline 60 & $>500$ & $>500$ & 138 & $>500$ & $>500$ & $>500$ & - \\
\hline 120 & $>500$ & $>500$ & 152 & $>500$ & $>500$ & $>500$ & 1496.0 \\
\hline
\end{tabular}

Following colonies were seen [table 6] for E. coli and Bacillus, for the following concentration of the seed powder of G. max.

Table 6: Colonies of G. max

\begin{tabular}{|c|c|c|c|c|c|c|c|}
\hline E. coli & & & & Bacillus & & & \\
\hline Time in min & $\begin{array}{l}\text { 0.1g } \\
\text { Plant sample }\end{array}$ & $\begin{array}{l}0.5 g \\
\text { Plant sample }\end{array}$ & $\begin{array}{l}\text { 1.0g } \\
\text { Plant sample }\end{array}$ & $\begin{array}{l}\text { 0.1g } \\
\text { Plant sample }\end{array}$ & $\begin{array}{l}0.5 g \\
\text { Plant sample }\end{array}$ & $\begin{array}{l}\text { 1.0g } \\
\text { Plant sample }\end{array}$ & Control \\
\hline 30 & 40.0 & 96.0 & 48.0 & 72.0 & 80.0 & 80.0 & 59.0 \\
\hline 60 & 80.0 & 72.0 & 144.0 & 56.0 & 64.0 & 144.0 & - \\
\hline 120 & 80.0 & 80.0 & 124.0 & 112.0 & 104.0 & 120.0 & 80.0 \\
\hline
\end{tabular}

Following colonies were seen [table 7] for E. coli and Bacillus, for the following concentration of the seed powder of M. pudica. 
Table 7: Colonies of M. pudica

\begin{tabular}{|c|c|c|c|c|c|c|c|}
\hline E. coli & & & & Bacillus & & & \\
\hline Time in min & $\begin{array}{l}\text { 0.1g } \\
\text { Plant sample }\end{array}$ & $\begin{array}{l}0.5 g \\
\text { Plant sample }\end{array}$ & $\begin{array}{l}1.0 \mathrm{~g} \\
\text { Plant sample }\end{array}$ & $\begin{array}{l}\text { 0.1g } \\
\text { Plant sample }\end{array}$ & $\begin{array}{l}0.5 g \\
\text { Plant sample }\end{array}$ & $\begin{array}{l}1.0 \mathrm{~g} \\
\text { Plant sample }\end{array}$ & Control \\
\hline 30 & 80.0 & 88.0 & 136.0 & $>500$ & $>500$ & $>500$ & 50.0 \\
\hline 60 & 64.0 & 88.0 & 120.0 & $>500$ & $>500$ & $>500$ & - \\
\hline 120 & 56.0 & 80.0 & 96.0 & $>500$ & $>500$ & $>500$ & 80.0 \\
\hline
\end{tabular}

Following colonies were seen [table 8] for E. coli and Bacillus, for the following concentration of the seed powder of T. stans

Table 8: Colonies of T. stans

\begin{tabular}{|c|c|c|c|c|c|c|c|}
\hline E. coli & & & & Bacillus & & & \\
\hline Time in min & $\begin{array}{l}\text { 0.1g } \\
\text { Plant sample }\end{array}$ & $\begin{array}{l}\text { 0.5g } \\
\text { Plant sample }\end{array}$ & $\begin{array}{l}\text { 1.0g } \\
\text { Plant sample }\end{array}$ & $\begin{array}{l}\text { 0.1g } \\
\text { Plant sample }\end{array}$ & $\begin{array}{l}0.5 g \\
\text { Plant sample }\end{array}$ & $\begin{array}{l}\text { 1.0g } \\
\text { Plant sample }\end{array}$ & Control \\
\hline 30 & 104.0 & 168.0 & 176.0 & 200.0 & 192.0 & 144.0 & 200 \\
\hline 60 & 120.0 & 160.0 & 224.0 & 224.0 & 192.0 & 272.0 & - \\
\hline 120 & 112.0 & 128.0 & 184.0 & 208.0 & 156.0 & 224.0 & 400.0 \\
\hline
\end{tabular}

Following colony forming units were seen [table 9] for E. coli and Bacillus, for the following concentration of the seed powder of $M$. prureins.

Table 9: Colony forming units for M. prureins

\begin{tabular}{lllllll}
\hline E. coli & & & & Bacillus & \\
\hline Time in min & $\mathbf{0 . 1 g}$ & $\mathbf{0 . 5 g}$ & $\mathbf{1 . 0 g}$ & $\mathbf{0 . 1 g}$ & $\mathbf{0 . 5 g}$ & $\begin{array}{l}\mathbf{1 . 0 g} \\
\text { Plant sample }\end{array}$ \\
& Plant sample & Plant sample & Plant sample & Plant sample & $\begin{array}{l}\text { Control } \\
\text { Plant sample }\end{array}$ \\
\hline 30 & 13.1644 & - & - & 13.4249 & 11.6021 \\
60 & 13.2041 & - & - & 13.4249 & 12.0000 \\
120 & 13.3766 & - & 12.5051 & 13.4116 & 13.4249 & 13.6937 \\
\hline
\end{tabular}

Following colony forming units were seen [table 10] for E. coli and Bacillus, for the following concentration of the seed powder of $C$. fistula.

Table 10: Colony forming units for C. fistula

\begin{tabular}{lllllll}
\hline E. coli & & & \multicolumn{3}{c}{ Bacillus } \\
\hline Time in min & $\mathbf{0 . 1 g}$ & $\mathbf{0 . 5 g}$ & $\mathbf{1 . 0 g}$ & $\mathbf{0 . 1 g}$ & $\mathbf{0 . 5 g}$ & $\mathbf{1 . 0 g}$ \\
& Plant sample & Plant sample & Plant sample & Plant sample & Plant sample & Plant sample \\
\hline 30 & 14.2294 & - & - & - & - & - \\
60 & 14.0674 & - & 11.9031 & - & - & - \\
120 & - & - & 12.8062 & - & - & - \\
\hline
\end{tabular}

Following colony forming units were seen [table 11] for E. coli and Bacillus, for the following concentration of the seed powder of L. odoratus

Table 11: Colony forming units for L. odoratus

\begin{tabular}{|c|c|c|c|c|c|c|c|}
\hline \multirow{2}{*}{$\begin{array}{l}\text { E. coli } \\
\text { Time in min }\end{array}$} & \multicolumn{7}{|c|}{ Bacillus } \\
\hline & $\begin{array}{l}0.1 \mathrm{~g} \\
\text { Plant sample } \\
\end{array}$ & $\begin{array}{l}0.5 g \\
\text { Plant sample } \\
\end{array}$ & $\begin{array}{l}\text { 1.0g } \\
\text { Plant sample }\end{array}$ & $\begin{array}{l}\text { 0.1g } \\
\text { Plant sample }\end{array}$ & $\begin{array}{l}\text { 0.5g } \\
\text { Plant sample }\end{array}$ & $\begin{array}{l}\text { 1.0g } \\
\text { Plant sample }\end{array}$ & Control \\
\hline 30 & 14.0674 & - & 11.9031 & - & - & - & 11.9031 \\
\hline 60 & - & - & 12.8062 & - & - & - & - \\
\hline 120 & - & - & 13.4409 & - & - & - & 14.4760 \\
\hline
\end{tabular}

Following colony forming units were seen [table 12] for E. coli and Bacillus, for the following concentration of the seed powder of G. max.

Table 12: Colony forming units for G. max

\begin{tabular}{|c|c|c|c|c|c|c|c|}
\hline \multirow{3}{*}{$\begin{array}{l}\text { E. coli } \\
\text { Time in min }\end{array}$} & \multicolumn{7}{|c|}{ Bacillus } \\
\hline & $0.1 \mathrm{~g}$ & $0.5 \mathrm{~g}$ & $1.0 \mathrm{~g}$ & $0.1 \mathrm{~g}$ & $0.5 \mathrm{~g}$ & $1.0 \mathrm{~g}$ & Control \\
\hline & Plant sample & Plant sample & Plant sample & Plant sample & Plant sample & Plant sample & \\
\hline 30 & 12.9031 & 13.2833 & 12.9823 & 13.51584 & 13.1072 & 13.3802 & 13.5200 \\
\hline 60 & 13.2041 & 13.1584 & 13.4594 & 13.0492 & 13.3181 & 13.3802 & - \\
\hline 120 & 13.3181 & 13.2041 & 13.4082 & 13.4082 & 13.6021 & 13.4594 & 13.2041 \\
\hline
\end{tabular}

Following colony forming units were seen [table 13] for E. coli and Bacillus, for the following concentration of the seed powder of $M$. pudica.

Table 13: Colony forming units for M. pudica

\begin{tabular}{|c|c|c|c|c|c|c|c|}
\hline E. coli & & & & Bacillus & & & \\
\hline Time in min & $\begin{array}{l}\text { 0.1g } \\
\text { Plant sample }\end{array}$ & $\begin{array}{l}0.5 \mathrm{~g} \\
\text { Plant sample }\end{array}$ & $\begin{array}{l}1.0 \mathrm{~g} \\
\text { Plant sample }\end{array}$ & $\begin{array}{l}\text { 0.1g } \\
\text { Plant sample }\end{array}$ & $\begin{array}{l}0.5 \mathrm{~g} \\
\text { Plant sample }\end{array}$ & $\begin{array}{l}1.0 \mathrm{~g} \\
\text { Plant sample }\end{array}$ & Control \\
\hline 30 & 13.2041 & 13.2455 & 13.4346 & - & - & - & 13.0000 \\
\hline 60 & 13.1072 & 13.2455 & 13.3802 & - & - & - & - \\
\hline 120 & 13.0492 & 13.2041 & 13.2833 & - & - & - & 13.2041 \\
\hline
\end{tabular}

Following colony forming units were seen [table 14] for E. coli and Bacillus, for the following concentration of the seed powder of $T$. stans. 
Table 14: Colony forming units for T. stans

\begin{tabular}{|c|c|c|c|c|c|c|c|}
\hline \multirow{2}{*}{$\frac{E \text {. coli }}{\text { Time in min }}$} & \multicolumn{7}{|c|}{ Bacillus } \\
\hline & $\begin{array}{l}\text { 0.1g } \\
\text { Plant sample }\end{array}$ & $\begin{array}{l}0.5 \mathrm{~g} \\
\text { Plant sample }\end{array}$ & $\begin{array}{l}1.0 \mathrm{~g} \\
\text { Plant sample }\end{array}$ & $\begin{array}{l}\text { 0.1g } \\
\text { Plant sample }\end{array}$ & $\begin{array}{l}0.5 \mathrm{~g} \\
\text { Plant sample }\end{array}$ & $\begin{array}{l}1.0 \mathrm{~g} \\
\text { Plant sample }\end{array}$ & Control \\
\hline 30 & 13.3181 & 13.5465 & 13.5658 & 13.6021 & 13.5843 & 13.7356 & 13.6021 \\
\hline 60 & 13.5465 & 13.5051 & 13.5658 & 13.6191 & 13.5843 & 13.4594 & - \\
\hline 120 & 13.3802 & 13.4082 & 13.5465 & 13.6513 & 13.5284 & 13.4829 & 13.9031 \\
\hline
\end{tabular}

\section{DISCUSSION}

The estimation of L-dopa was carried out in M. pruriens using HPLC, and found that it contains $2 \%$ of Levodopa by weight, Levodopa is commercially used for the treatment of Parkinson's disease [32].

Estimation of Levodopa through HPLC method is considered to be the most convenient, simple, and accurate method [33].

It was observed that the other samples did not contain Levodopa, and the results were statistically analyzed using the one-way ANOVA test, no significance difference was observed in the present study between the plant species and the concentration of the Levodopa.

The result was further clarified by Cytoscape and ChemMine where, the phytochemicals of all the plant species were checked for similarity and showed no similarity in the phytochemical class, though they belong to the same family Leguminosae.

Thus, further studies can be conducted to understand the formation of L-dopa in M. pruriens. It takes place through the shikimic pathway, converting the simple carbohydrate precursors, which are derived from the glycolysis and pentose phosphate pathway to aromatic amino acids tyrosine, phenylalanine, tryptophan. Whereas the plants belonging to the same family does not show any similarity in the presence of phytochemicals as well as the compound [34]. The compound L-dopa belongs to the family of catecholamines, which are the aromatic compounds with a phenyl ring and 3,4-hydroxy groups. This catecholamines are active compounds in the plant, but these when enter the human body, behave as neurotransmitters [35]. The other plant samples though from the same family, shows absence of the active compound mainly because of the absence of carboxylic derivatives, in them. This L-dopa not only is useful to humans in terms of a neurotransmitter but also the synthetically synthesized levodopa has adverse effects on human health, whereas the Levodopa extracted from plants is twice more effective and has probably no side-effects [36]. The compound is found effective for the treatment of the disease, as per the study conducted on 178 patients between November 1969-December 1972, the drug showed improvement in 126 patients, thus making its potentiality marked as the drug which can improve the conditions of PD patients [37]. The concentration of levodopa was higher in M. pruriens than in any other plant; the cotyledon powder is the significant source of the drug and is found to be more potential than the synthetic. Thus, proving its high significant value in having antiparkinsonian activity when compared to the synthetically synthesized. The velvet beans are also commonly called the magic beans due to the presence of Nicotine adenine dinucleotide (NADH) and Q-10 which shows the therapeutic effects on the patients [38]. Emphasizing, the herbal drugs for the treatment, the drug extracted from the plant is usually devoid of any harmful side effects though the standardization, quality control, safety and marketing is yet to be conducted [39]. The seeds samples of the selected plants were subjected to the antimicrobial activity towards the selected bacteria, the bacteria selected were, E. coli and Bacillus. The plants showed positive results towards the test.

All parts of M. pruriens possesses the properties, but seeds possesses both astringent, laxative, anti-helminthic, thus proves to be potential for the antimicrobial test $[40,41]$. The bioactive compounds present in the crude seed powder, can be stated as the main compound which plays a major role in inhibiting the microbial activity of the bacteria $[42,43]$ Coming to the seeds of Lathyrus odoratus, the presence of fatty acids exhibits the activity [44]. G. max, which is abundantly used as the dietary supplement, also shows the inhibitory effect towards the microbial test, it is also found potential against the pathogenic bacteria, and is also recommended for the treatment of infectious diseases [45]. M. pudica apart from its pharmacological values, can also be used against the treatment to microbial activity, whereas the activity is attributed by the presence of bioactive like, terpenoids, flavonoids, glycosides, alkaloids, quinines, phenols, tannins, saponins and coumarin. Such bioactives have both bactericidal as well as antimicrobial activity $[46,47]$. $T$. stans show anti-inflammatory and analgesic activities, this is because of the presence of oil in the seeds which after quantification sums up to $15 \%$ of the weight [48]. Thus, the plant samples can be used for its antimicrobial activity, though they lack the efficacy to produce the compound levodopa.

\section{CONCLUSION}

As the present studies state, that the active compound Levodopa is only seen present in M. pruriens, the formation of this compound is through the shikimate pathway. Since 5 plants were studied from the same family, and 1 plant from another family as a comparative standard, showed no presence of the active compound, further studies can be conducted in understanding the formation of the compound whereas the Genes responsible for it.

The anti-microbial activity of the plants towards the selected bacteria proved to be positive as it is mainly due to the presence of flavonoids and other compounds which inhibit the bacteriostatic property. Further studies can be conducted in isolating the compounds responsible for the bacteriostatic property.

\section{ACKNOWLEDGMENT}

The author would like to express her gratitude towards the institution Christ (Deemed to be university) Banglore-29, for providing the scientific temper, fostering me to quench my curiosity in the right direction, fulfilling with all the required material resources and optimum mentorship by my revered guide Fr. Jobi Xavier (HOD Dept. of Life-sciences), last but not the least I'm thankful for the emotional, mental and psychological support with which my family equipped me amidst teeming failures and lead me to complete this research.

\section{FUNDING}

Nil

\section{AUTHORS CONTRIBUTIONS}

All the authors have contributed equally.

\section{CONFLICT OF INTERESTS}

\section{Declare none}

\section{REFERENCES}

1. J Parkinson. An essay on the shaking palsy 1817 . J Neuropsychiatry Clin Neurosci 2002;14:223-36.

2. G DeMaagd, A Philip. Parkinson's disease and its management part 1: disease entity, risk factors, pathophysiology, clinical presentation, and diagnosis. P T 2015;40:504-32.

3. Parkinson's Foundation. Available from: https://www.parkinson.org/UnderstandingParkinsons/Statistics. [Last accessed on 27 Feb 2020]

4. Overview | Parkinson's disease in adults | Guidance | NICE. Available from: https://www.nice.org.uk/guidance/NG71. [Last accessed on 27 Feb 2020]

5. G Pezzoli, M Zini. Levodopa in Parkinson's disease: From the past to the future. Expert Opinion Pharmacother 2010;11:627-35. 
6. Levodopa (L-Dopa)-PubMed. Available from: https://pubmed. ncbi.nlm.nih.gov/29489269-levodopa-l-dopa/ [Last accessed on $28 \mathrm{Feb} 2020]$.

7. M Furlanut, J Furlanut M, P Benetello. Erratum: monitoring of L-DOPA concentrations in Parkinson's disease. Pharmacol Res 2001;43:423-7.

8. S Ovallath, B Sulthana. Levodopa: history and therapeutic applications. Ann Indian Acad Neurol 2017;20:185-9.

9. PubChem Update: Improved Access to Chemical Data-PubMed; 2019. Available from: https://pubmed.ncbi.nlm.nih.gov/ 30371825-pubchem-2019-update-improved-access-tochemical-data/. [Last accessed on 28 Feb 2020]

10. PubChem Substance and Compound Databases-PubMed. Available from: https://pubmed.ncbi.nlm.nih.gov/26400175pubchem-substance-and-compound-databases/. [Last accessed on $28 \mathrm{Feb} 2020]$

11. Y Djoumbou Feunang. ClassyFire: automated chemical classification with a comprehensive, computable taxonomy. J Cheminform 2016;8:1-20.

12. L Sathiyanarayanan, S Arulmozhi. Mucuna pruriens linn.-a comprehensive review. Pharmacogn Rev 2007;1:157-62.

13. R Katzenshlager. Mucuna pruriens in Parkinson's disease: a double blind clinical and pharmacological study. J Neurol Neurosurg Psychiatry 2004;75:1672-7.

14. H Pulikkalpura, R Kurup, PJ Mathew, S Baby. Levodopa in mucuna pruriens and its degradation. Sci Rep 2015;5:1-9.

15. A Ali. Cassia fistula linn. a review of phytochemical and pharmacological studies. Int J Pharm Sci Res 2014;5:2125-30.

16. JF Kennedy, PMG Palva, MTS Corella, MSM Cavalcanti, LCBB Coelho. Lectins, versatile proteins of recognition: a review. Carbohydrate Polymers 1995;26:219-30.

17. AV Pawar, SJ Patil, SG Killedar. Uses of Cassia Fistula Linn as a medicinal plant. Pawar Aarti V Int J Adv Res Dev 2017;2:85-91.

18. Lathyrus odoratus (sweet pea). Available from: https://www. cabi.org/isc/datasheet/31584. [Last accessed on $28 \mathrm{Feb} 2020$ ]

19. HG Fried, S Narayanan, B Fallen. Characterization of a soybean (Glycine max L. Merr.) germplasm collection for root traits. PLoS One 2018;13:e0200463.

20. SR Mentreddy, AI Mohamed, N Joshee, AK Yadav. Edamame: a nutritious vegetable crop, ASHS Press; 2002.

21. RJ Hamilton. Lipid analysis in oils and fats. Springer US; 1997.

22. H Ahmad, S Sehgal, A Mishra, R Gupta. Mimosa pudica L. (Laajvanti): an overview. Pharmacogn Rev 2012;6:115-24.

23. R Rajendran, $\mathrm{R}$ Sundararajan. Preliminary phytochemical analysis and anti-bacterial activity of Mimosa pudica linn leaves. Int J Pharma Bio Sci 2010;5:53-5.

24. B Govindappa, M Sadananda, TS Channabasava, R Jeevitha, MK Pooja, KS Vinay. Antimicrobial, antioxidant activity and phytochemical screening of tecoma stans (L.) Juss. ex Kunth. J Phytol 2011;3:68-76.

25. S Verma. Phytochemical and pharmacological review study on Tecoma Stans Linn; 2016.

26. Online Shopping site in India: Shop Online for Mobiles, Books, Watches, Shoes and More-Amazon. In. Available From: https://www.amazon.in/ [Last accessed on 29 Feb 2020]

27. RN Vora, AN Joshi, NC Joshi. Comparison of l-dopa content in two varieties of broad beans (Vicia Faba) by different extraction techniques. World J Pharm Med Res 2017;3:271-4.

28. T Hasegawa, K Takahashi, T Fukiwake, M Saijo, Y Motoki. Enantiomeric determination of DOPA in dietary supplements containing mucuna pruriens by liquid chromatography/mass spectrometry. J Food Hyg Soc Japan 2013;54:379-83.

29. BN Singh, AKS Rawat, RM Bhagat, BR Singh. Black tea: phytochemicals, cancer chemoprevention, and clinical studies. Crit Rev Food Sci Nutr 2017;57:1394-410.
30. EE Bolton, Y Wang, PA Thiessen, SH Bryant. Chapter 12 PubChem: Integrated Platform of Small Molecules and Biological Activities Elsevier BV; 2008.

31. AK Virk, C Kumari, A Tripathi, A Kakade, X Li, S Kulshrestha. Development and efficacy analysis of a Moringa oleifera based potable water purification kit. J Water Process Eng 2018;27:37-46.

32. A Soumyanath, T Denne, A Hiller, S Ramachandran, L Shinto. Analysis of levodopa content in commercial mucuna pruriens products using high-performance liquid chromatography with fluorescence detection. J Altern Complement Med 2018;24:182-6

33. H Haibin, $\mathrm{S}$ Jian, $\mathrm{T}$ Yechong. Determination of levodopa in mucuna macrocarpa wall by HPLC. Guangxi Zhiwu 2004;24:460-2.

34. AR Soares, R Marchiosi, R de Cassia Siqueira Soares, RB de Lima, WD dos Santos, O Ferrarese Filho. The role of L-DOPA in plants. Plant Signaling and Behavior 2014;9:e28275.

35. A Kulma, J Szopa. Catecholamines are active compounds in plants. Plant Sci 2007;172:433-40.

36. KB Ramya, $\mathrm{S}$ Thaakur. Herbs containing L-dopa: an update. Anc Sci Life 2007;27:50-5.

37. KM Shaw, AJ Lees, GM Stern. The impact of treatment with levodopa on parkinson's disease. QJM An Int J Med 1980;49:283-93.

38. BV Manyam, M Dhanasekaran, TA Hare. Neuroprotective effects of the antiparkinson drug mucuna pruriens. Phyther Res 2004;18:706-12.

39. JB Calixto. Efficacy, safety, quality control, marketing and regulatory guidelines for herbal medicines (phytotherapeutic agents). Braz J Med Biol Res 2000;33:179-89.

40. SA Mastan, P Janaki Ramayya, L Mutyala Naidu, K Mallikarjuna. Antimicrobial activity of various extracts of Mucuna pruriens leaves. Biomed Pharmacol J 2009;2:55-60.

41. L Taylor. The healing power of rainforest herbs : a guide to understanding and using herbal medicinals. Square One Publishers; 2005.

42. SL Jothy. Bioassay directed isolation of active compounds with antiyeast activity from a cassia fistula seed extract. Molecules 2011;16:7583-92.

43. V Duraipandiyan, S Ignacimuthu. Antibacterial and antifungal activity of cassia fistula L.: an ethnomedicinal plant. J Ethnopharmacol 2007;112:590-4.

44. S Mohamed. Anthocyanins and fatty acids from the flowers of lathyrus odoratus L. and their antimicrobial activity. Planta Med 2009;75:175.

45. SA Hosseini Chaleshtori, M Ataie Kachoie, SM Hashemi Jazi. Antibacterial effects of the methanolic extract of glycine max (Soybean). Microbiol Res (Pavia) 2017;8. Doi:10.4081/ mr.2017.7319

46. N Gandhiraja, S Sriram, V Meenaa, JK Srilakshmi, C Sasikumar, $\mathrm{R}$ Rajeswari. Phytochemical screening and antimicrobial activity of the plant extracts of mimosa pudica l. against selected microbes; 2009.

47. R Singh Tomar, V Shrivastava, S Kaushik. In vitro efficacy of methanolic extract of mimosa pudica against selected microorganisms for its broad spectrum antimicrobial activity miomosa pudica-a broad spectrum antimicrobial herb view project biosynthesis of gold nanoparticles view project microorganisms for its broad spectrum antimicrobial activity. Int J Curr Microbiol Appl Sci 2014;3:780-4.

48. HM Sbihi, S Mokbli, IA Nehdi, SI Al-Resayes. Physico-chemical properties of tecoma stans linn. seed oil: a new crop for vegetable oil. Nat Prod Res 2015;29:1249-55. 